\title{
KEWENANGAN PEMERINTAH DAERAH TERHADAP HAK ULAYAT MASYARAKAT HUKUM ADAT SETELAH BERLAKUNYA UNDANG-UNDANG NOMOR 32 TAHUN 2004
}

\author{
Oleh: Adonia Ivonne Laturette
}

\begin{abstract}
The national development faster and rapidly, often requires the state to make the arrangement in all areas including land use that requires people to surrender their land to the State for use for the public interest. Industrial park development, highway construction, agriculture, plantation, mining and so on are some of the basic legitimacy of the state used in the takeover of customary rights of indigenous peoples

With the enactment of Act Number 32 Year 2004 on Regional Autonomy which generally contains the enforcement of the implementation of the handover of authority to the state's right to control local government district or city. In this regard it with the enactment of regional autonomy which is the state's right to control the delegation of authority in the area of land to local governments, local governments should be able to run the authority, especially in the area of land with due regard to the interests of local communities indigenous people themselves in the territory of the Republic of Indonesia .
\end{abstract}

Keyword:

\section{A. LATAR BELAKANG.}

Tidak dapat dipungkiri bahwa Undang-Undang No. 32 Tahun 2004 tentang Pemerintahan Daerah, sampai hari ini telah menjadi satu sebab lahirnya ribuan kebijakan daerah.Undang-undang tersebut yang memelopori penyerahan sejumlah kewenangan pemerintahan kepada pemerintah daerah, mendorong pemerintah untuk membuat berbagai kebijakan daerah. Kebijakan daerah dalam otonomi daerah adalah sebagai salah satu insrtumen dalam rangka melaksanakan urusan pemerintah. Penyerahan sejumlah kewenangan pemerintah kepada pemerintah daerah pada dasarnya merupakan pembagian kekuasaan yang diperlukan dalam penyelenggaraan kepentingan rakyat dan menghindari adanya kesewenang-wenangan oleh lembaga kekuasaan negara.

Dalam konteks negara Indonesia yang menganut prinsip negara kesatuan sebagaimana yang tertuang dalam dalam Pasal 1 ayat (1) Undang-Undang Dasar 1945 yang berbunyi : "Negara Indonesia ialah Negara Keasatuan yang berbentuk Republik" menganut paham pembagian kekuasaan. Sebagai negara kesatuan maka kedaulatan negara adalah tunggal, tidak tersebar pada negara-negara federal/ serikat. Oleh sebab itu sistem pemerintahan dalam negara kesatuan adalah sentralisasi artinya pemerintah pusat memegang kekuasan penuh.

Prinsip pembagian kekuasaan dikemukakan oleh Philipus M. Hadjon bahwa : "Dengan mendasarkan pada ketentuan Undang-Undang Dasar 1945, terdapat 2 (dua) pola pembagian kekuasaan negara yaitu pembagian kekuasaan negara secara horizontal dan secara vertikal. Pembagian kekuasaan negara secara horizontal adalah pembagian kekuasaan negara kepada organ utama negara yang dalam ketatanegaraan kita di sebut Lembaga Negara, sedangkan pembagian negara secara vertikal adalah pembagian kekuasaan negara 
antara pemerintah pusat dan pemetrintah daerah." 1

Terhadap pembagian kekuasaan antara pemerintah pusat dan daerah di atur dalam Pasal 18 Undang-Undang Dasar 1945 menyebutkan:

(1) Negara Kesatuan Republik Indonesia dibagi atas daerahdaerah provinsi dan provinsi itu dibagi atas kabupaten dan kota, yang tiap-tiap provinsi, kabupaten dan kota itu mempunyai pemerintahan daerah.

(2) Pemerintah provinsi, daerah kabupaten, dan kota mengatur dan mengurus sendiri urusan pemerintahan menurut asas otonomi dan tugas pembantuan

Dari ketentuan Pasal 18 ayat (1) dan (2) UUD 1945 ini menunjukan bahwa Indonesia yang merupakan negara kesatuan di bagi atas daerah-daerah provinsi kemudian provinsi tersubut dibagi atas kabupaten dan kota yang mana masingmasing mengatur dan mengurus sendiri urusan pemerintah menurut asas otonomi dan tugas pembantuan. Penyelenggaraan urusan pemerintah merupakan pelaksanaan antara pemerintah dan pemerintah daerah provinsi, kabupaten dan kota saling terkait, tergantung dan sinergis sebagai 1 (satu) sistem pemerintahan.

Pemerintahan pusat dan daerah merupakan satu kesatuan yang mencerminkan keutuhan bentuk negara kesatuan, tetapi masing-masing mempunyai kewenangan, tugas dan dan tanggung jawab yang berbeda. Pembagian kekuasaan antara pemerintah pusat dan daerah sangatlah penting mengingat wilayah Indonesia yang sangat luas terdiri dari puluhan ribu pulau besar dan kecil dan penduduknya yang terdiri dari berbagai suku, ras dan agama. Dengan adanya pembentukan pemerintahan daerah otonom, masyarakat yang berada

1 Philipus M. Hadjon, Sistem Pembagian Kekuasaan Negara, kuliah Umum di Universitas Warmadewa Denpasar Bali pada tiap-tiap daerah dapat berperan aktif dalam peningkatan kesejateraan bersama.

Dalam Pasal 1 angka 5 UndangUndang Nomor 32 Tahun 2004 tentang Otonomi Daerah memberi pengertian Otonomi Daerah adalah hak, wewenang dan kewajiban daerah otonom untuk mengatur dan mengurus sendiri urusan pemerintahan dan kepentingan masyarakat setempat sesuai dengan peraturan perundang-undangan. Namun demikian walaupun mengandung pengertian kebebasan mengatur diri sendiri, bukan berarti kebebasan secara penuh. Hal ini disebabkan karena Otonomi Daerah harus dijalankan sesuai dengan batas-batas yang yang ditentukan oleh peraturan perundang-undangan.

Sedangkan pengertian daerah otonom dalam Pasal 1 angka 6 adalah kesatuan masyarakat hukum yang mempunyai batas-batas wilayah, yang berwenang mengatur dan mengurus urusan pemerintah dan kepentingan masyarakat setempat menurut prakasa sendiri, berdasarkan aspirasi masyarakat dalam sistem Negara Kesatuan Republik Indonesia.

Dengan berlakunya Undang-Undang Nomor 32 tahun 2004 tentang Otonomi Daerah yang secara umum berisi penegakan adanya penyerahan pelaksanaan kewenangan hak menguasai negara kepada pemerintah daerah kabupaten atau kota. Pasal 4 ayat (1) jo Pasal 5 ayat (1) dan ayat (4), merumuskan bahwa dalam rangka pelaksanaan asas desentralisasi maka di bentuk dan di susun daerah propinsi, daerah kabupaten dan daerah kota yang berwenang mengatur dan mengurus kepentingan masyarakat setempat dengan tetap mempertimbangkan kemampuan otonomi, potensi daerah, sosial budaya, sosial politik, jumlah penduduk, luas daerah dan perimbangan lain yang memungkinkan terselengaranya otonomi daerah. Sedangkan asas-asas yang mengatur hubungan antara pemerintah pusat dan daerah yakni :

a. Asas Desentralisasi.

Dalam Pasal 1 angka 7 diberikan pengertian Desentralisasi penyerahan 
wewenang oleh pemerintah kepada daerah otonom untuk mengatur dan mengurus urusan pemerintahan dalam sistem negara Kesatuan Republik Indonesia.

b Asas Dekonsentrasi

Dalam Pasal 1 angka 8 adalah pelimpahan wewenang pemerintahan oleh pemerintah kepada Gubernur sebagai wakil pemerintah dan/atau kepada instansi vertikal di wilayah tertentu.

c. Asas Tugas Pembantuan

Dalam Pasal 1 angka 9 tugas pembantuan adalah penugasan dari pemerintah provinsi kepada kabupaten/kota/ atau desa serta dari pemerintah kabupaten/kota kepada desa untuk melaksanakan tugas tertentu.

Berdasarkan asas-asas yang mengatur hubungan antara pemerintah pusat dan daerah seperti yang telah dikemukakan, jelas terlihat bahwa walaupun Negara Indonesia dibagi menjadi daerah otonom tetapi tidak mempunyai kedaulatan sendiri. Pemerintah daerah hanya menjalankan kewenangan yang diberikan oleh pemerintah. Kewenangan yang diberikan oleh Pemerintah Pusat pada Pemerintah Daerah diatur dalam Pasal 10 ayat (1) yang menyatakan bahwa Pemerintahan Daerah menyelenggarakan urusan pemerintahan yang yang menjadi kewenangannya, kecuali urusan pemerintahan yang oleh undangundang ini ditentukan menjadi urusan Pemerintah. Sedangkan urusan pemerintahan yag ditentukan menjadi urusan pemerintah diatur dalam Pasal 10 ayat (3) yaitu :
a. Politik luar negeri
b. Pertahanan
c. Keamanan
d. Yustisi
e. Moneter dan fiskal nasional; dan
f. Agama.

Dengan demikian yang tidak tercantum dalam Pasal 10 ayat (3) menjadi urusan pemerintahan yang merupakan kewenangan dari pemerintah daerah.

\section{B. PEMBAHASAN}

\section{Kewenangan Pemerintah Daerah Di Bidang Pertanahan}

Pasal 33 ayat (3) Undang-Undang Dasar 1945 yang berbunyi "Bumi, air dan kekayaan alam yang terkandung didalamnya dikuasai oleh Negara dan dipergunakan sebesar-besarnya untuk kemakmuran rakyat." Dengan demikian terlihat bahwa kepentingan untuk mencapai sebesarbesarnya kemakmuran rakyat merupakan dasar bagi dikuasainya tanah oleh negara.

Dalam Pasal 2 ayat (1) UUPA disebutkan bahwa "Atas dasar ketentuan Pasal 33 ayat (3) Undang-Undang Dasar dan hal-hal sebagai yang dimaksud dalam Pasal 1, bumi air, dan ruang angkasa termasuk kekayaan alam yang terkandung didalamnya itu pada tingkatan tertinggi dikuasai oleh Negara, sebagi organisasi kekuasaan seluruh rakyat" jelas terlihat penjabaran dan pengertian dari Pasal 33 ayat (3) bahwa, Negara adalah pihak yang berkuasa, diberikan kekuasaan oleh rakyat tidak memiliki atau mempergunakan tanah semata-mata untuk keperluannya sendiri, tetapi untuk mengatur penggunaa penggunaan dan peruntukan tanah agar dapat tercipta kemakmuran rakyat secara meningkat dan merata.

Pelaksanaan wewenang hak menguasai negara atas tanah dapat dilaksanakan oleh pemerintah daerah dan masyarakat hukum lainnya. Hal ini diatur dalam Pasal 2 ayat (4) UUPA : "Hak menguasai dari Negara tersebut di atas pelaksanaanya dapat dikuasakan kepada Daerah-daerah Swatantra dan masyarakat masyarakat hukum adat, sekedar diperlukan dan tidak bertentangan dengan dengan kepentingan nasional, menurut ketentuanketentuan peraturan Pemerintah. Pasal 2 ayat (4) UUPA ini secara umum segala sesuatu masih bergantung pada pusat tanpa mempunyai suatu pedoman yang jelas perihal pelimpahan pelaksanan kekuasaaan negara atas tanah itu diserahkan kepada 
daerah dan masyarakat Hukum Adat. Kemudian dalam penjelasan Pasal 2 ayat (4) juga disebutkan bahwa :

"ketentuan ayat (4) adalah bersangkutan dengan asas otonomi dan medebewind dalam penyelenggaraan pemerintahan daerah. Soal agraria menurut sifatnya dan pada asasnya merupakan tugas Pemerintahan Pusat (Pasal 33 ayat (3) Undang-Undang Dasar 1945). Dengan demikian maka pelimpahan wewenang untuk melaksanakan hak menguasai dari negara atas tanah merupakan medebewind. Segala sesuatunya akan diselenggarakan menurut keperluannya dan sudah barang tentu tidak boleh bertentangan dengan kepentingan nasional. Wewenang dalam bidang agraria merupakan sumber keuangan bagi daerah itu".

Dengan mencermati isi Pasal 2 ayat (4) dan penjelasannya tersebut, kewenangan Hak Menguasai Negara dilaksanakan oleh Pemerintah Pusat secara sentralistiik. Hal ini jelas terlihat dari kalimat menurut sifatnya dan pada asasnya merupakan tugas pemerintah pusat. Dalam pelaksanaannya pemerintah pusat dapat menguasakan (memberi) kuasa kepada pemerintah daerah, namun hal tersebut bukan suatu keharusan. Oleh sebab itu apabila pemerintah pusat memberikan kuasa kepada pemerintah daerah untuk melaksanakan kewenangan itu hanya bersifat medebewind atau dalam kerangka membantu pemerintah pusat.

Adapun hubungan kewenangan antara pemerintah pusat dengan pemerintah daerah mengalami periode berlakunya undang-undang pemerintahan daerah. Demikian pula dengan istilah yang digunakan oleh perundang-undangan di bidang pemerintahan daerah juga mengalami perubahan. Undang-Undang Nomor 22 Tahun 1999 memakai istilah kewenangan dalam bidang pemerintahan sedangkan Undang-Undang Nomor 32 Tahun 2004 menggunakan istilah urusan pemerintahan.

Untuk itu dalam pelaksanaan otonomi daerah, sebagai tindak lanjut dari
Pasal 2 ayat (4) UUPA, maka dalam Undang-Undang Nomor 22 Tahun 1999 tentang pemerintahan daerah Pasal 11 ayat (2) mengatur bahwa "Bidang pemerintahan daerah Kabupaten dan daerah Kota meliputi pekerjaan umum, kesehatan, pendidikan dan kebudayaan, pertanian dan perhubungan, industri dan perdagangan, penanaman modal, lingkungan hidup, pertanahan , koperesi dan pengajaran". Pengaturan dalam pasal 11 ayat (2) tersebut menunjukan bahwa pertanahan merupakan salah satu bidang urusan pemerintahan daerah yang wajib dilaksanakan.

Selanjutnya setalah berlaku UndangUndang No 32 Tahun 2004 sebagai penyempurnaan Undang-Undang No 22 Tahun 1999 tentang Pemerintahan Daerah. Pasal 11 ayat (2) Undang-Undang No. 32 Tahun 2004 mengaitkan dengan pembagian urusan menyatakan "Penyelenggaraan urusan pemerintahan sebagaimana dimaksud pada ayat (1) merupakan pelaksanaan hubungan kewenangan antara Pemerintah dan pemerintahan daerah propinsi, kabupaten dan kota atau pemerintahan daerah yang saling terkait, tergantung, dan sinergis sebagai satu sistem pemerintahan. Sehingga urusan di bidang pertanahan khususnya berkaitan dengan aspek hukum pertanahan bagi terwujudnya unifikasi hukum pertanahan dan kepastian hukum di bidang pertanahan tetap menjadi wewenang pemerintah pusat.

Selanjutnya dalam Pasal 13 ayat (1) mengatur wewenang propinsi sebagai berikut :

a. perencanaan dan pengendalian pembangunan;

b. perencanaan, pemanfaatan dan pengawasan tata ruang;

c. penyelenggaraan ketertiban umum dan ketentraman masyarakat;

d. penyediaan sarana dan prasarana umum;

e. penanganan bidang kesehatan;

f. penyelenggaraan pendidikan dan alokasi sumber daya manusia potensial;

g. penanggulangan masalah sosial lintas kabupaten/kota; 
h. pelayanan bidang ketenagakerjaan lintas kabupaten/kota;

i. fasilitasi pengembangan koperasi, usaha kecil, dan menengah termasuk lintas kabupaten/kota;

j. pengendalian lingkungan hidup;

k. pelayanan pertanahan termasuk lintas kabupaten/kota;

1. pelayanan kependudukan, dan catatan sipil;

m. pelayanan administrasi umum pemerintahan;

n. pelayanan administrasi penanaman modal termasuk lintas kabupaten/kota;

o. penyelenggaraan pelayanan dasar lainnya yang belum dapat dilaksanakan oleh kabupaten/kota; dan

p. urusan wajib lainnya yang diamanatkan oleh peraturan perundang-undangan.

Pasal 14 ayat (1) yang mengatur wewenang pemerintah kabupaten/kota menyebutkan bahwa :

"Urusan wajib yang menjadi kewenangan pemerintahan daerah untuk kabupaten/kota merupakan urusan yang berskala kabupaten/kota meliputi :

a. perencanaan dan pengendalian pembangunan;

b. perencanaan, pemanfaatan, dan pengawasan tata ruang;

c. penyelenggaraan ketertiban umum dan ketentraman masyarakat;

d. penyediaan sarana dan prasarana umum;

e. penanganan bidang kesehatan;

f. penyelenggatraan pendidikan;

g. penanggulangan masalah sosial;

h. pelayanan bidang ketenagakerjaan;

i. fasilitasi pengembangan koperasi, usaha kecil, dan menengah;

j. pengendalian lingkungan hidup;

k. pelayanan pertanahan;

1. pelayanan kependudukan, dan catatan sipil;

m. pelayanan administrasi umum pemerintahan;

n. pelayanan admistrasi penanaman modal; o. penyelenggaraan pelayanan dasar lainnya; dan

p. urusan wajib lainnya yang diamanatkan oleh perundangundangan."

Berkaitan dengan kewenangan pemerintah daerah di bidang pertanahan seperti yang termuat dalam Pasal 13 ayat (1) huruf k dan Pasal 14 ayat (1) huruf k tentang Pelayanan Pertanahan. Tentunya berkatian juga dengan Hak Ulayat masyarakat hukum adat. Dalam Pasal 22 Undang-Undang No 32 Tahun 2004 disebutkan bahwa "dalam menjalankan otonomi, daerah mempunyai kewajiban untuk melindungi masyarakat, menjaga persatuan, kesatuan, dan kerukunan nasional, serta keutuhan negara Kesatuan Republik Indonesia, termasuk masyarakat Hukum Adat."

Dengan berlakunya otonomi daerah yang merupakan pelimpahan kewenangan hak menguasai negara di bidang pertanahan kepada pemerintah daerah, seharusnya pemerintah daerah dapat menjalankan kewenangannya di bidang pertanahan dengan memperhatikan kepentingan dari masyarakat daerah itu sendiri di dalam wilayah negara Republik Indonesia.

Hak menguasai negara yang kewenangan pelaksanaanya sebagian dilimpahkan pada pemerintah daerah di kenal sebagai hak pengelolaan. Sehubungan denga hak pengelolaan Boedi Harsono mengatakan hak pengelolaaan tidak disebut dalam UUPA, tetapi hanya disinggung dalam Penjelasan umum angka II.2 alinea terakhir. Kemudian kita jumpai ketentuan pengaturannya dalam Peraturan Menteri Agraria No 9 Tahun 1965 tentang Pelaksanaan Konversi Hak Penguasaan atas Tanah Negara dan ketentuan-ketentuan kebijaksanaan selanjutnya. Pasal 6 ayat (1) yakni :

a. Merencanakan peruntukan dan penggunaan tersebut

b. Menggunakan tanah tersebut untuk keperluan pelaksanaan tugasnya.

c. Menyerahkan bagian-bagian dari tanah tersebut kepada pihak ketiga dengan hak 
pakai yang berjangka waktu 6 (enam) tahun

d. Menerima uang pemasukan/ganti rugi/atau uang wajib tahunan

Pasal 28 Peraturan Menteri Dalam

Negeri Nomor 5 Tahun 1973 :

a. Merencanakan peruntukan dan penggunaan tanah yang bersangkutan;

b. Menggunakan tanah tersebut untuk keperluan tugasnya;

c. Menyerahkan bagian-bagian dari tanah itu kepada pihak ketiga dengan hak pakai yang berjangka waktu 6 (enam) tahun;

d. Menerima uang pemasukan dan/atau uang wajib tahunan.

Pasal 3 Peraturan Menteri Dalam

Negeri Nomor 5 Tahun 1974 Hak pengelolaan adalah hak yang berisikan wewenang untuk:

a. Merencanakan peruntukan dan penggunaan tanah yang bersangkutan;

b. Menggunakan tanah tersebut untuk keperluan pelaksanaan usahanya

c. Menyerahkan bagian-bagian dari pada tanah itu kepada pihak ketiga menurut persyaratan yang ditentukan oleh perusahaan pemegang hak tersebut, yang meliputi segi-segi peruntukan dan penggunaan, jangka waktu dan keuangannya, dengan ketentuan bahwa pemberian hak atas tanah kepada pihak ketiga yang bersangkutan dilakukan oleh pejabat-pejabat yang berwenang menurut Peraturan Menteri dalam Negeri Nomor 6 Tahun 1972.

Pasal 1 ayat (1) Peraturan menteri dalam Negeri Nomor 1 Tahun 1977. Hak pengelolaan adalah hak yang memberi wewenang untuk;

a. merencanakan peruntukan dan penggunaan tanah yang bersangkutan;

b. menggunakan tanah tersebut untuk keperluan pelaksanaan usahanya;

c. menyerahkan bagian-bagian dari pada tanah itu kepada pihak ketiga menurut persyaratan yang ditentukan oleh perusahaan pemegang hak tersebut, yang meliputi segi-segi peruntukan, penggunaan, jangka waktu dan keuangannnya dengan ketentuan bahwa pemberian hak atas tanah kepada pihak ketiga yang bersangkutan dilakukan oleh pejabat yang berwenang sesuai dengan peraturan perundangan yang berlaku.

Dari apa yang dikemukakan diatas tentang pengertian dan lingkup hak pengelolaan yang diatur dalan berbagai peraturan perundang-undangan yang telah disebutkan di atas dapat walaupun dirumuskan secara berbeda namun mempunyai makna yang sama bagi pemegang hak tersebut dilihat dari kewenangan yang diberikan kepadanya. Kewenangan dimaksud adalah merencanakan peruntukan dan penggunaan tanah yang bersangkutan untuk kepentingan sendiri juga dapat memberikan bagian dari tanah tersebut kepada pihak lain dengan memungut uang pemasukan.

Dengan demikian lahirnya UndangUndang No. 32 Tahun 2004 tentang Pemerintahan Daerah secara tegas mengatur tentang kewenangan pemerintah di bidang pertanahan sebagai pemerintahan wajib Pemerintah daerah memiliki kewenangan mengatur masalah peruntukan dan penggunaan pertanahan di daerah maka tentunya termasuk didalamnya kewenangan untuk mengatur tanah-tanah ulayat masyarakat Hukum Adat.

Bahkan keberadaan dari masyarakat hukum adat diakui dan diatur dalam Pasal 2 ayat (9) Undang-Undang No. 32 Tahun 2004 yang meyebutkan: "Negara mengakui dan menghormati kesatuan-kesatuan masyarakat hukum beserta hak tradisionalnya sepanjang masih hidup dan sesuai dengan perkembangan masyarakat masyarakat dan prinsip negara kesatuan"

Dengan pengakuan yang diberikan kepada masyarakat hukum beserta hak tradisionalnya (dalam hal ini masyarakat Hukum Adat), maka pemerintah daerah dalam mengeluarkan kebijakan-kebijakan tentunya harus memperhatikan keberadaan masyarakat hukum adat yang ada dengan 
tidak bertindak semaunya dalam menjalankan kewenangannya.

Dalam Undang-umdang Nomor 32 Tahun 2004, juga mengatur mengenai kewenangan pemerintah daerah dalam melegalkan keberadaan masyarakat hukum adat melalui Peraturan Daerah, antara lain dalam :

a. Pasal 203 ayat (3) menyebutkan :Pemilihan kepala desa dalam kesatuan masyarakat dapat beserta hak tradisionalnya sepanjang masih hidup dan yang diakui keberadaannya berlaku ketentuan, Hukum Adat setempat yang ditetapkan dalam perda dengan berpedoman pada peraturan pemerintah.

b. Penjelasan Pasal 204 menyebutkan: masa jabatan kepala desa dalam ketentuan ini dapat dikecualikan bagi kesatuan masyarakat hukum adat yang keberadaannya masih hidup dan diakui yang ditetapkan dengan Perda.

Dari apa yang di kemukan di atas dalam Pasal 203 dan penjelasan Pasal 204 tersebut jelas terlihat bahwa kesatuan masyarakat Hukum Adat yang masih hidup dan diakui keberadaannya, ditetapkan dengan Peraturan Daerah. Dan kewenangan pembuatan peraturan Daerah terdapat pada pemerintah Daerah.

Adapun dalam Pasal 22 butir a Undang-Undang N0. 32 Tahun 2002 disebutkan bahwa dalam menyelengarakan otonomi, daerah mempunyai kewajiban melindungi masyarakat, menjaga persatuan, kesatuan dan kerukunan nasional, serta keutuhan negara kesaruan Republik Indonesia. Dengan memperhatikan Pasal ini jelas terlihat Hak Ulayat masyarakat hukum adat juga perlu mendapat perlindungan dari pemerintah daerah apabila hak masyarakat tersebut makin terpinggirkan akibat ketidakadilan dan penindasan-penindasan terhadap Hak Ulayat masyarakat Hukum Adat.

\section{Pengaturan Hak Ulayat Dalam Peraturan Daerah}

Masyarakat hukum adat di Indonesia pada umumnya menempati wilayah yang terdiri dari daratan dengan kondisi dataran, pegunungan, wilayah pesisir pantai serta beberapa pulau kecil. Mereka menempati wilayah yang disebut sebagai wilayah kekuasaan, wilayah kepunyaan, wilayah ulayat, wilayah petuanan dan lain sebagainya. Dalam literature Indonesia disebut sebagai Hak Ulayat, atau sering dikatakan juga sebagai wilayah ulayat. Kalau berbicara tentang wilayah ulayat maka pembicaraan itu merujuk pada satuan geografis. Sedangkan jika berbicara tentang hak, maka yang tercakup wewenangwewenang atau otoritas yang didasarkan pada kemauan untuk melakukan atau tidak melakukan sesuatu di atas wilayah ulayat.

Wilayah ulayat pada umumnya merupakan wilayah strategis karena di dalamnya terdapat ruang-ruang yang secara alami terwujud dalam kesatuan geografis. Di dalamnya terkait unsur-unsur ekenomi, sosial, budaya dan politik, yang terbentuk berdasarkan perkembangan sejarah, hukum, administrasi dan fungsional. Kondisi geografi yang terbentuk secara alami ini terdiri dari berbagai ruang antara lain ruang permukiman, ruang penguasahaan di darat, danau, sungai dan perairan pesisir maupun laut. Wilayah ulayat di satuan-satuan masyarakat hukum adat di Indonesia pada umumnya berada di bentangan darat baik di dataran, pegunungan, dan meliputi sungai, danau, bukit maupun lembah sampai di wilayah pesisi, laut bahkan pulau-pulau di sekitarnya .

Masyarakat hukum adat, merupakan masyarakat yang masih mempraktekkan kebiasaan-kebiasaan secara berulang-ulang yang disertai sanksi-sanksi tertentu, dalam memanfaatkan sumber daya alam yang ada di dalamnya, baik di darat maupun di pesisir, yang diperlukan bagi kehidupan mereka. Kegiatan-kegiatan yang memanfaatkan sumber daya alam baik di darat maupun di wilayah pesisir yang ada 
dipermukaan maupun yang berada di dalam tanah memperlihatkan kecenderungan adanya pemeliharaan lingkungan terhadap kerusakan.

Dewasa ini terdapat tantangan terhadap kehidupan Masyarakat hukum adat di berbagai tempat. Terlihat dimana-mana bahwa pemanfaatan sumber daya alam yang berada di hutan maupun atas mineral di dalam tanah yang dilakukan pengusahapengusaha besar, cenderung merusak lingkungan, merugikan masyarakat hukum adat, bahkan pemerintah di kabupaten yang memiliki otonomi pemerintahan atras wilayahnya. Di lain pihak pula, kebiasaankebiasaan yang dipraktekkan secara berulang-ulang di berbagai wilayah memperlihatkan variasi yang cenderung individualistik, sekalipun di beberapa desa masih memperlihatkan karakter komunal. Walaupun demikian, pemanfaatan sumber daya di dalam wilayah ulayat hampir seluruhnya ditujukan bagi pemenuhan kepentingan ekonomi dan sosial dan budaya. Namun kecenderungan adanya eksploitasi sumber daya alam yang dilakukan oleh perusahan-perusahan dengan teknologi maju, lebih mengancam kelestarian lingkungan dan kerugian terhadap masyarakat setempat.

Sementara itu, kekayaan alam mineral yang ada di perut bumi yang dapat ditambang seperti emas, ataupun kekayaan alam berupa air bawah tanah, dan kekayaan alam berupa energi, seluruhnya berada dalam wilayah ulayat. Di atas wilayah ulayat ini terdapat kesatuan aktivitas dari masyarakat. Kesatuan aktivitas di bidang ekonomi, sosial, budaya bahkan politik, dan tempat permukiman di dalam wilayah ulayat pada hakekatnya didasarkan pada prinsipprinsip yang diwariskan oleh leluhur masyarakat hukum adat setempat, warisan mana mencirikan perbedaan-perbedaan yang dipengaruhi oleh sistem pemerintahan sebelumnya, seperti Kesultanan, dan juga oleh sistem masyarakat bebas pada masa lampau. Oleh karena itu, terdapat juga perbedaan ciri penguasaan dan pemanfaatan lahan di antara lingkup-lingkup masyarakat

Perlindungan terhadap sumber daya alam di lingkup ulayat masyarakat, dilakukan sedemikian rupa oleh lingkuplingkup masyarakat hukum adat. Perlindungan ini di dasarkan pada pandangan bahwa sumber daya alam yang ada, merupakan sumber kehidupan mereka dan (dahulu) merupakan sumber kehidupan junjungan mereka. Proteksi yang dilakukan masyarakat di desa-desa melalui hukum adatnya terhadap pihak luar desa yang hendak memanfaatkan tanah adalah dengan cara perlu adanya ijin dari kepala desa setempat bagi pihak luar tersebut. Selain itu masyarakat desa setempat harus memperoleh keuntungan dari pemanfaatan lahan, dengan cara bahwa pihak luar yang memanfaatkan lahan, harus tetap memelihara kelestarian lingkungan.

Dalam perkembangannya, pengakuan, penghormatan dan perlindungan terhadap Hak Ulayat telah tertuang dalam Peraturan Daerah. Beberapa daerah telah mempunyai peraturan perundang-undangan yang mengatur tentang Hak Ulayat yakni Peraturan Daerah Kabupaten Kampar Nomor 12 tahun 1999 Tentang Hak Tanah Ulayat (LD.2000-1), Peraturan Daerah kabupaten Lebak Nomor 32 Tahun 2001 tentang Perlindungan Atas Hak Ulayat Masyarakat Baduy. (LD 2001-5, TLD. 4) dan Peraturan Daerah Propinsi Nusa Tenggara Timur Nomor 8 Tahun 1974 tentang Pelaksanaan Penegasan Hak atas Tanah. (LN 1974-19).

Dalam perumusan Peraturan Daerah ini harus didasarkan pada landasanlandasan yang tepat. Terdapat 3 (tiga) landasan penting dalam proses pembentukan Undang-Undang yakni;

a. Landasan filosofi

b. Landasan yuridis

c. Landasan sosiologis

Landasan filosofis terkait dengan dengan hakikat dan urgensi pembentukannya. Landasan yuridis terkait sumber hukum yang menjastifikasi proses 
maupun substansinya. Landasan sosiologis terkait dengan aspek sosial, ekonomi dan kemasyarakatan lainnya, yang menjadi tujuan pembentukan aturan hukum tersebut. ${ }^{2}$

Perundang-undangan dikatakan mempunyai landasan filosofi (filosofische grondslag) apabila rumusannya atau normanormanya mendapatkan pembenaran (rechtvaardiging) dikaji secara filosofi, berarti mempunyai alasan yang dapat dibenarkan apabila dipikirkan secara mendalam. Alasan tersebut sesuai dengan cita-cita dan pandangan hidup manusia dalam pergaulan hidup masyarakat sesuai dengan cita-cita kebenaran (idee der waarheid) cita-cita keadilan (idee der gerechtigheid) ${ }^{3}$

Suatu

perundang-undangan

dikatakan mempunyai landasan sosiologis (sosiologis grondslag) apabila ketentuanketentuannya sesuai dengan keyakinan umum atau kesadaran hukum masyarakat. Hal ini penting agar perundang-undangan yang dibuat ditaati oleh masyarakat, tidak menjadi huruf-huruf mati belaka landasan yuridis (rechtsgrond) atau yang disebut juga landasan hukum atau dasar hukum ataupun legalitas adalah landasan atau dasar yang terdapat dalam ketentuan-ketentuan hukum yang lebih tinggi derajatnya. Landasan yuridis ini dapat dibedakan pula menjadi 2 (dua) macam yaitu : landasan yuridis yang beraspek formal yaitu ketentuan-ketentuan hukum yang memberi kewenangan kepada pembentuknya. ${ }^{4}$

2 Marthinus J. Sapteno, Permusan Asas-Asas Substansial Dan fungsinya Dalam Pembentukan Undang-Undang. Ringkasan Disertasi Program Pasca Sarjana Universitas Airlangga Surabaya 2007

3 Amiroedin Syarif, Perundang-undangan: Dasar, Jenis dan Teknik Membuatnya, bina Akasara, Jakarta, 1987 hal 91 dalam Disertasi Elli Ruslina, Pasal 33 Undang-Undang dasar 1945 Sebagai dasar perekonomian Indonesia: Telah Terjadi Penyimpangan Terhadap Mandat konstitusi, Pasca sarjana Fakultas Hukum Universitas Indonesia , Jakarta Juli 2010

4 Elli Ruslina, Pasal 33 Undang-Undang dasar 1945 Sebagai dasar perekonomian Indonesia:

\section{P E N U T U P}

Dengan berlakunya Undang-Undang Nomor 32 tahun 2004 tentang Otonomi Daerah yang secara umum berisi penegakan adanya penyerahan pelaksanaan kewenangan hak menguasai negara kepada pemerintah daerah kabupaten atau kota. Dengan demikian Undang-undang Nomor 23 tahun2004 tentang otonomi Daerah ini juga secara tegas mengatur tentang kewenangan pemerintah di bidang pertanahan sebagai Pemerintahan wajib Pemerintah daerah memiliki kewenangan mengatur masalah peruntukan dan penggunaan pertanahan di daerah maka tentunya termasuk didalamnya kewenangan untuk mengatur tanah-tanah ulayat masyarakat Hukum Adat.

Bahkan keberadaan dari masyarakat hukum adat diakui dan diatur dalam Pasal 2 ayat (9) Undang-Undang No. 32 Tahun 2004 yang berbunyi : "Negara mengakui dan menghormati kesatuan-kesatuan masyarakat hukum beserta hak tradisionalnya sepanjang masih hidup dan sesuai dengan perkembangan masyarakat masyarakat dan prinsip negara kesatuan"

Dengan pengakuan yang diberikan kepada masyarakat hukum beserta hak tradisionalnya (dalam hal ini masyarakat Hukum Adat), maka pemerintah daerah dalam mengeluarkan kebijakan-kebijakan tentunya harus memperhatikan keberadaan masyarakat hukum adat yang ada dengan tidak bertindak semaunya dalam menjalankan kewenangannya karena dengan adanya peraturan perundang-undangan yang baik akan banyak menunjang penyelenggaraan pemerintah maupun masyarakat (masyarakat Hukum Adat) dalam pembangunan, demi tercapainya tujuan-tujuan yang dinginkan. Untuk itulah perlu membuat suatu peraturan perundangundangan yang baik dengan persiapan yang

Telah Terjadi Penyimpangan Terhadap Mandat konstitusi, Pasca sarjana Fakultas Hukum Universitas Indonesia , Jakarta Juli 2010 
matang, menyangkut pengetahuan terhadap materi-materi yang akan diatur dalam perundang-undangan dan pengetahuan bagaimana menuangkan materi tersebut di dalam suatu peraturan perundang-undangan secara singkat dan jelas dan mudah dipahami.

\section{DAFTAR PUSTAKA}

Amiroedin Syarif, Perundang-undangan: Dasar, Jenis dan Teknik Membuatnya, bina Akasara, Jakarta, 1987 hal 91 dalam Disertasi Elli Ruslina, Pasal 33 Undang-Undang dasar 1945 Sebagai dasar perekonomian Indonesia: Telah Terjadi Penyimpangan Terhadap Mandat konstitusi, Pasca sarjana Fakultas Hukum Universitas Indonesia , Jakarta Juli 2010

Elli Ruslina, Pasal 33 Undang-Undang dasar 1945 Sebagai dasar perekonomian Indonesia: Telah Terjadi Penyimpangan Terhadap Mandat konstitusi, Pasca sarjana Fakultas Hukum Universitas Indonesia , Jakarta Juli 2010

Marthinus J. Sapteno, Permusan Asas-Asas Substansial Dan fungsinya Dalam Pembentukan UndangUndang. Ringkasan Disertasi Program Pasca Sarjana Universitas Airlangga Surabaya 2007

Philipus M. Hadjon, Sistem Pembagian Kekuasaan Negara, kuliah Umum di Universitas Warmadewa Denpasar Bali 